\title{
The Study of Economic Factors Affecting Sustainability of Rice Farming
}

\author{
Rachmiwati Yusuf ${ }^{1}$, Indra Fuadi ${ }^{2}$, Nurhayati ${ }^{1}$, Sri Swastika ${ }^{1}$ and Parlin \\ $\mathrm{H}_{\text {Sinaga }}{ }^{1}$ \\ ${ }^{1}$ Researcher of Riau Assessment Institute for Agricultural Technology, Pekanbaru, Riau \\ ${ }^{2}$ Plant Pest and Diseases Controller of Riau Food and Horticultural Plant Protection Center, Pekanbaru, \\ Riau \\ *Corresponding author: rachmi_2608@yahoo.co.id
}

\begin{abstract}
The study of economic factors affecting sustainability of rice farming was conducted from January to September 2018 in Siak Regency. This study aimed to identify economic factors that affect the sustainability of rice farming in Siak Regency. The number of respondents in this study was 203 farmers, determined by a margin of error of $7 \%$ of the total population of agricultural households. The economic parameters observed in this study were the availability of farmers' capital, availability of production facilities, price of unhulled rice, agrotourism potential, economic efficiency, and farmers' income level. The results showed that the availability of farmers' capital $(59.11 \%)$ was categorized as still lacking capital. Seed production facilities, fertilizers, and agricultural equipment are available following what is needed by farmers, except for the price of pesticides. The price of unhulled rice in Siak Regency is around Rp.4,500-Rp.4,700/kg, already above the Government Purchase Price of Rp.3,700-Rp.4,070/kg. Agrotourism objects that are becoming a trend and are currently in demand are a race using a tractor, a race to catch mice in the paddy fields before the rice is planted, a soccer match in the muddy fields after the fields are plowed and a competition to plant and harvest rice, both manually and using machines. Rice farming activities in Siak Regency are economically feasible to continue and profitable with 2.49-2.72Revenue Cost Ratio and 1.49-1.72 Benefit Cost Ratio.
\end{abstract}

Keywords: Economic factors, farm sustainability, lowland rice

\section{INTRODUCTION}

Sustainable agriculture can be considered successful if agricultural business development, human resources, complete facilities, and infrastructure are met and run well [1]; [2]; [3]. If not fulfilled, then the conversion of agricultural land cannot be avoided because the needs are increasingly complex. The conversion of land functions is driven by economic factors, where land use after conversion has a higher selling / rental value (land rent) than land use for rice fields. Another factor is due to the decreasing quality of the paddy fields or the lower opportunities for obtaining income from the land due to certain activities, such as the isolation of rice fields in rural areas due to land conversion in the vicinity. In a certain period, the rice fields in question will change to nonagricultural uses or be used for dryland agriculture. Conversion directly occurs as a result of landowners' decisions to convert their paddy fields to other uses, for example for the industry, housing, infrastructure, and facilities, or dryland agriculture

The conversion of agricultural land in Siak Regency tends to increase every year. The area of wetland farming in 2009 was 8,499 hectares [4] and in 2014 it was 4,675 hectares [5]. There was a reduction in the area of rice fields reaching 3,824 hectares in 5 years. Considering that the agricultural sector has a strategic and significant role in the national and regional economy, the local government of
Siak Regency has issued a policy of [6] Regional Regulation Number 2 of 2014 concerning the protection of sustainable food agricultural land. Through this Regional Regulation, it is hoped that there will be an impetus in the provision of sustainable agricultural food land, to prevent the loss of environmental protection benefits. If the regional government wants to strengthen food security, the government must protect the land conversion from happening. The many problems with the conversion of agricultural land that occur will certainly be a threat to food security in Siak Regency.

The regional agriculture office of Siak Regency has a vision of realizing tough, efficient, environmentally friendly, and agribusiness-oriented agriculture and seeks to strengthen food security through increased productivity, increasing cropping intensity, securing production, and developing food diversification. Each of these policies prohibits changing agricultural land use to non-agricultural uses. However, in reality, this policy cannot be an effective control system over the conversion of agricultural land that occurs. However, that does not mean it cannot because it depends on the political will of the government. Looking at the phenomena described above, it is necessary to identify the causes of the ineffectiveness of the existing policies and how to implement the implementation of the Law on preventing the conversion of agricultural land functions 
and how the steps are taken by the government in addressing the existing problems related to the function of land conversion.

The form of policy implementation carried out by the Siak Regency regional government in controlling landuse change is based on [6] Regional Regulation Number 02 of 2014 concerning the Protection of Sustainable Food Agricultural Land. Article 6 states that this regional regulation aims to 1). Creating and ensuring the availability of sustainable agricultural land; 2). Controlling the conversion of land for sustainable food agriculture; 3).Realizing self-sufficiency, resilience, and regional food sovereignty; 4). Increase empowerment, income, and welfare for farmers; 5). Provide business certainty for agricultural business actors; 6).Creating an ecological balance; 7).Prevent wasteful agricultural infrastructure investment.

The efforts to support the success of this program require the assurance of paddy fields as sustainable food agriculture. However, there are still parties who change the function of rice farming land to oil palm plantations and from year to year, this is because farmers consider oil palm plantation activities to be more promising when compared to rice fields, especially at this time the prospect of palm oil commodity is very bright in the world vegetable oil trade which of course affects the economic adequacy of farmer households. The purpose of this study was to identify economic factors that affect the sustainability of the lowland rice business in Siak Regency.

\section{METHODOLOGY}

The research was conducted in four sub-districts of rice centers in Siak Regency, i.e. Bunga Raya, Sabak Auh, Sungai Apit and Sungai Mandau Districts. This study used a survey method and number of samples was calculated based on the Slovin in [7] with a margin of error of $7 \%$ of the total population of farmer households in Siak Regency. The number of farmer households in Siak Regency is 36,609 , so the total sample of respondents consisted of 203 farmer households. Considering the different number of farmer households in each sub-district in Siak Regency, the proportion of the number of farmer households for each district will also be different. The proportion of the number of respondents in each sub-district and village was calculated using the minimum number of respondents approach based on the modified rice field area of [8]. The results of the calculation of the number of farmer household respondents in each village and sub-district in Siak Regency are presented in Table 1.

The research scope includes the economic aspects of the field survey which is strengthened by the opinion of experts. The type of data required in this study consists of primary data and secondary data. The determination of respondents from the community was carried out by purposive sampling, with representative criteria, which is the farming community associated with rice farming. Interviews and discussions were also conducted with informal and formal figures as key respondents. The determination of respondents for the expert and stakeholder was also carried out by using a purposive sampling technique (according to the objectives). The selected respondents have correlated expertise to the problem being studied. Some considerations in determining the expert to be the respondent according to [9] are having experience whose is relevant to the problem being studied, has a reputation, has high credibility, and was at the research location.

Table 1. Number of Respondents in Siak Regency

\begin{tabular}{|c|c|c|c|}
\hline $\begin{array}{c}\text { Sub- } \\
\text { District }\end{array}$ & Village & $\begin{array}{l}\text { Rice Field } \\
\text { Area }\left(\mathrm{hm}^{-2}\right)\end{array}$ & $\begin{array}{c}\text { Number of } \\
\text { Respondents }\end{array}$ \\
\hline \multirow{5}{*}{$\begin{array}{l}\text { Bunga } \\
\text { Raya }\end{array}$} & $\begin{array}{l}\text { Kemuning } \\
\text { Muda }\end{array}$ & 504 & 21 \\
\hline & Bunga Raya & 474 & 20 \\
\hline & $\begin{array}{l}\text { Tuah } \\
\text { Indrapura }\end{array}$ & 395 & 17 \\
\hline & Jayapura & 338.5 & 14 \\
\hline & $\begin{array}{l}\text { Buantan } \\
\text { Lestari }\end{array}$ & 233 & 10 \\
\hline \multirow{3}{*}{$\begin{array}{l}\text { Sabak } \\
\text { Auh }\end{array}$} & Belading & 475 & 20 \\
\hline & $\begin{array}{l}\text { Sungai } \\
\text { Tengah }\end{array}$ & 380 & 16 \\
\hline & Laksamana & 350 & 15 \\
\hline \multirow{3}{*}{$\begin{array}{l}\text { Sungai } \\
\text { Apit }\end{array}$} & Teluk Lanus & 673 & 28 \\
\hline & Harapan & 55 & 2 \\
\hline & Sungai Apit & 50 & 2 \\
\hline \multirow{3}{*}{$\begin{array}{l}\text { Sungai } \\
\text { Mandau }\end{array}$} & $\begin{array}{l}\text { Muara } \\
\text { Kelantan }\end{array}$ & 373 & 16 \\
\hline & $\begin{array}{l}\text { Muara } \\
\text { Bungkal }\end{array}$ & 326 & 14 \\
\hline & Lubuk Jering & 180 & 8 \\
\hline \multicolumn{2}{|l|}{ Jumlah } & $4,836.5$ & 203 \\
\hline
\end{tabular}

The economic parameters observed in this study were the availability of farmer,s capital, the availability of production facilities, the price of unhulled rice, the potential for agro-tourism, economic efficiency, and farmer income level. The parameters of the availability of farmer's capital were categorized based on having no capital, lack of capital, sufficient capital, and no problems with capital. The production facilities studied were seeds, fertilizers, pesticides and agricultural equipment. The availability of production facilities that meet "the right six" criteria, namely the right place, time, quantity, type, quality, and price for farmers is very important for the success of farm management. The right six according to the Technology Application Level (TAL) method refers to [10] using predetermined score values as in Table 2 . The criteria in Table 2 are used as a reference for assessing the accuracy of the production fasilities used by farmers in Siak Regency.

Table2. The Criteria for Availability of Lowland Rice Farming Production Facilities

\begin{tabular}{|l|c|c|l|}
\hline $\begin{array}{c}\text { Availability of production } \\
\text { facilities }\end{array}$ & Score & $\begin{array}{l}\text { Total } \\
\text { Score }\end{array}$ & \multicolumn{1}{|c|}{ Criteria } \\
\hline $\begin{array}{l}\text { Not available when } \\
\text { needed }\end{array}$ & 5 & $<45$ & $\begin{array}{l}\text { Not } \\
\text { fulfilled }\end{array}$ \\
\hline $\begin{array}{l}\text { Available but less than } \\
\text { required }\end{array}$ & 10 & $45-75$ & $\begin{array}{l}\text { Less } \\
\text { fulfilled }\end{array}$ \\
\hline Available as needed & 15 & $>75$ & Fulfilled \\
\hline
\end{tabular}

Source: [9] 


\section{RESULTS AND DISCUSSION}

\subsection{The Availability of Farmer Capital}

The availability of adequate capital is needed to be able to carry out the rice farming process effectively and efficiently, but not all farmers have sufficient capital. The availability of farmer capital in Siak Regency is presented in Table 3.

Table 3 explains that in general the availability of capital for farmers in Siak Regency is categorized as undercapitalized (59.11\%). Accessibility of farmers to capital sources is still very limited, especially for farmers who control narrow land. From the results of discussions with farmers, extension agents, and the sub-district head, it was found that it was difficult for farmers to get access from banks because they could not fulfill banking regulations and also because the credit allocation for the agricultural sector was relatively small. According to [11], credit allocation for agriculture is only $6 \%$.

[12]; [13]; [14] state that the fundamental problem faced by farmers is weak capital. The low level of capital control also causes the low level of technology adoption at the farm level which in turn has an impact on farm productivity. The factor of lack of capital, to develop farming usually becomes an obstacle for farmers to implement technology in its entirety this is because there is a positive correlation between capital and increased productivity. [15] stated that the availability of capital, technology, and farmers' knowledge is crucial to the sustainability of the agricultural business, furthermore, [16] added that the ease with which farmers can access market information and the promotion of products produced is a success factor in developing agricultural businesses.

Most of the farmers' capital availability in Siak Regency $59.11 \%$ still categorized as under-capitalized and $33.50 \%$ are categorized as sufficient capitalized farmers and $7.39 \%$ are categorized as very sufficient capitalized. Farmers who do not have problems with the capital in Bunga Raya Subdistrict have their own or in groups of agricultural machinery equipment, so that the need for agricultural machinery equipment in their area can be fulfilled, they can even rent out the agricultural machinery equipment to other districts.

Table 3.The Availability of Farmer Capital in Siak Regency

\begin{tabular}{|l|c|c|c|c|}
\hline \multirow{2}{*}{ Sub-District } & \multicolumn{4}{c|}{ The Availability of Farmer Capital } \\
\cline { 2 - 5 } & $\begin{array}{c}\text { No Capital } \\
\text { people (\%) }\end{array}$ & $\begin{array}{c}\text { Lack Of Capital } \\
\text { people (\%) }\end{array}$ & $\begin{array}{c}\text { Sufficient Capital } \\
\text { people (\%) }\end{array}$ & $\begin{array}{c}\text { Very Sufficient Capital } \\
\text { people }(\%)\end{array}$ \\
\hline Bunga Raya & $0(0.00)$ & $42(51.22)$ & $31(37.80)$ & $9(10.98)$ \\
\hline Sabak Auh & $0(0.00)$ & $33(64.71)$ & $15(29.41)$ & $3(5.88)$ \\
\hline Sungai Apit & $0(0.00)$ & $22(68.75)$ & $8(25.00)$ & $2(6.25)$ \\
\hline Sungai Mandau & $0(0.00)$ & $23(60.53)$ & $14(36.84)$ & $1(2.63)$ \\
\hline Total & $0(0.00)$ & $120(59.11)$ & $68(33.50)$ & $15(7.39)$ \\
\hline
\end{tabular}

The factor of low capital for farming causes low rice field productivity and low farmer income. If this goes on for a long time, farmers will rent or sell their fields to other people. If the buyer is not interested in planting rice, the rice fields will be converted to other functions so that the rice fields are not sustainable.

Capital is needed so that all schedules in rice farming can be carried out on time, such as in the payment of labor wages for land cultivation, seed distribution, planting, fertilization, weeding, spraying of pests, and plant maintenance, and other works. If one activity is not carried out on time, it will affect production. Capital is needed in addition to paying for labor as well as for the provision of production facilities (seeds, fertilizers, and pesticides) which farmers feel the more expensive the price, the greater the capital issued by farmers, the greater the amount of income received by farmers [17].

The source of funds from farmer households is sometimes insufficient to finance an increase in farming, generally, farmer households are small farmers and have small capital. The government has made efforts to increase the accessibility of farmers and the availability of capital sources through various programs such as the development of agricultural microfinance institutions, Rural Agribusiness Development, Food and Energy Security Credit and various other programs. Government policy support is needed for the sustainability of lowland rice farming in Siak Regency. This is in line with the results of research by [18] which states that the sustainability of the agricultural business is not only the responsibility of farmers but also by government policies.

The results of the study show that there are still many farmers who only use their capital for their farming. The reasons for farmers to use their capital include 1) their capital is sufficient to do rice farming; 2) Not knowing credit loan procedures; 3) Difficult loanprocedures; 4) Has no collateral. Availability of sources of bank paddy farming capital and formal sources of financing Banks and credit institutions are widely available sources of financing, however, many respondent farmers still access financing from program credit, such as Rural Agribusiness Development which is managed by Farmer Group Association in their area. The reason why farmers prefer to borrow from Gapoktan is because the process is easier, the service is relatively small ( $1.8 \%$ for 6 months) and does not require collateral.

\subsection{The Availability of Production Facilities}

The availability of production facilities in the right place, time, quantity, type, quality, and affordable price for farmers is very important for the success of farm management. [19] stated that the support of adequate facilities and infrastructure and good cooperation within farmer groups will create a strong and sustainable local food system.

The results showed that for Bunga Raya District, the means of producing seeds, fertilizers, pesticides, and 
agricultural equipment were available according to what farmers needed. According to the Technology Application Level method referring to the results of research by [9] using a predetermined score value as in Table 2 , the average number of score criteria 6 is greater than 75 , which means it is the right criteria, as well as for the other 3 subdistricts except for the criteria for agricultural equipment, the other 3 sub-districts gave the number a small score of 75 which means that the means of production are available but less than needed (Table 4).

Tabel 4. The Average Availability of Lowland Rice Farming Production Facilities

\begin{tabular}{|c|c|c|c|c|c|c|c|}
\hline Production Facilities & Time & Place & Amount & Variety & Quality & Cost & Total Score \\
\hline \multicolumn{8}{|l|}{ Bunga Raya } \\
\hline Seed & 15.00 & 15.00 & 15.00 & 15.00 & 10.00 & 10.00 & 80.00 \\
\hline Fertilizer & 15.00 & 15.00 & 15.00 & 10.00 & 15.00 & 10.00 & 80.00 \\
\hline Pesticide & 15.00 & 15.00 & 15.00 & 15.00 & 15.00 & 10.00 & 85.00 \\
\hline Equipment & 15.00 & 15.00 & 15.00 & 15.00 & 10.00 & 10.00 & 80.00 \\
\hline \multicolumn{8}{|l|}{ Sabak Auh } \\
\hline Seed & 15.00 & 15.00 & 15.00 & 15.00 & 10.00 & 10.00 & 80.00 \\
\hline Fertilizer & 15.00 & 15.00 & 15.00 & 10.00 & 15.00 & 10.00 & 80.00 \\
\hline Pesticide & 15.00 & 15.00 & 15.00 & 15.00 & 15.00 & 10.00 & 85.00 \\
\hline Equipment & 15.00 & 15.00 & 10.00 & 10.00 & 10.00 & 10.00 & 70.00 \\
\hline \multicolumn{8}{|l|}{ Sungai Apit } \\
\hline Seed & 10.00 & 15.00 & 15.00 & 15.00 & 10.00 & 10.00 & 75.00 \\
\hline Fertilizer & 15.00 & 15.00 & 15.00 & 10.00 & 15.00 & 10.00 & 80.00 \\
\hline Pesticide & 15.00 & 15.00 & 15.00 & 15.00 & 15.00 & 10.00 & 85.00 \\
\hline Equipment & 15.00 & 15.00 & 10.00 & 10.00 & 10.00 & 10.00 & 70.00 \\
\hline \multicolumn{8}{|l|}{ Sungai Mandau } \\
\hline Seed & 15.00 & 15.00 & 15.00 & 15.00 & 10.00 & 10.00 & 80.00 \\
\hline Fertilizer & 15.00 & 15.00 & 15.00 & 10.00 & 15.00 & 10.00 & 80.00 \\
\hline Pesticide & 15.00 & 15.00 & 15.00 & 15.00 & 15.00 & 10.00 & 85.00 \\
\hline Equipment & 15.00 & 15.00 & 10.00 & 10.00 & 10.00 & 10.00 & 70.00 \\
\hline
\end{tabular}

Table 4 shows the highest score found for the means of producing pesticides. The average number is 15 , it means that input products are available as needed, except for pesticide prices. The score obtained for the 4 subdistricts is 10 , meaning that input production is available but in terms of price it is not in accordance with the ability of the farmers, however, pesticide as production facilities in 4 sub-districts are available as needed with 85 as the total score.

\subsection{The Price of Unhulled Rice}

The results showed that to achieve price stability for unhulled rice, the government has set a base price and a maximum price. The base price is intended to protect farmers as producers from falling prices for unhulled rice during harvest season, while the maximum price is intended to protect consumers, especially from price hikes during the dry season. The concept of the basic price was then adjusted to the Basic Government Purchase Price as of January 1, 2012, then to the Government Purchase Price through Presidential Instruction No. 5 of 2015. The price of harvested dry unhulled rice set by the government at IDR $3,700 / \mathrm{kg}$ for Siak Regency has not been found. The price of unhulled rice for all sub-districts is already above the government purchase price (Table 5).

The concept of the maximum price is then outlined in the policy of the highest retail price as stated in the Regulation of the Minister of Trade No. 57 / M-DAG / PER / 8/2017 concerning determination of the highest retail price for grain. The policy of determining highest retail price that has been carried out so far for both harvested dried grain and unhulled rice is based on moisture content and vacuum content. Harvest dried grain is a form of unprocessed grain with a moisture content of $25 \%$ and a maximum dirt of $10 \%$.

Farmers generally sell their products as harvested dried grain, while unhulled rice that has been dried and is ready to be milled into rice, generally having a water content of $14 \%$ and $3 \%$ dirt. The government has indeed set the price of harvested dried grain for farmers through a moisture content of $25 \%$ and a vacuum content of $10 \%$. However, this is not the case, at least for farmers in Siak District. Data obtained in the field during the main harvest season of June-July 2018, the average quality of harvested dried grain sold by farmers is $16-20 \%$ moisture content, 5$7 \%$ empty content, thus it can be said that the quality of harvested dried grain in Siak Regency is transacted by farmers has been above the government purchase price for harvested dried grain.

The results showed that the price of harvested dried grain in Siak Regency ranges from IDR. 4,500-4,700 / kg, depending on the quality of grain-based on long round grains and round short grains. Long grain is agreed by both parties who transact as better grain quality and more expensive on the market than short-grain, even though the quality of long or short grain can come from different rice varieties, as stated by [20] that each varieties will give varying yields on the number of tillers, total number of panicles, the weight of filled grain, plant height and the grain shape.

This price is already above the government purchase price (IDR. 3,700). Through the government purchase price policy, the Government hopes that rice production can be increased to meet domestic supply needs; the stability of rice prices; income of farmers, and 
rice farming increases and encourages national economic growth [21]. Usually, the price of unhulled rice in Bunga Raya Sub-district is always IDR. 100/kg higher than in Sabak Auh and Sungai Mandau sub-district, on the other hand, the price of grain in Sungai Apit District is often IDR. 100/kg lower than in Sabak Auh and Sungai Mandau Subdistricts. This is due to the influence of a wider area of land, closer distances, and better road conditions in Bunga Raya (Table 5).

The government has issued a policy of flexibility in the purchase price of Bulog's harvested dried grain which can flex $10 \%$ from IDR. 3,700-4,070 per $\mathrm{kg}$, but when compared to the current harvested dried grain price the government purchase price is still lower, plus if traders from outside the province enter, the price of unhulled rice can reach IDR. 4,800/kg. This is also the reason why until July 2018, Bulog's rice absorption in general for all regions is still low. The low absorption of Bulog is due to the difficulty of absorbing farmer's grain because the price of grain at the farmer level is still above the government purchase price. The high purchase price of grain offered by traders, especially from outside the region, has made farmers prefer to sell their unhulled rice to traders. The Siak Regency Government cannot prohibit farmers from selling their unhulled rice to traders outside the region and cannot prohibit outside traders from entering Siak. In fulfilling the need for rice, Siak Regency still imports from outside the region, in other words, Siak buys its rice back to meet the existing shortage. This occurs because the local government has not yet provided maximum post-harvest institutional security. The high purchase price of grain offered by traders, especially from outside the region, has made farmers prefer to sell their unhulled rice to traders. The Siak Regency Government cannot prohibit farmers from selling their unhulled rice to traders outside the region and cannot prohibit outside traders from entering Siak. In fulfilling the need for rice, Siak Regency still imports from outside the region, in other words, Siak buys its rice back to meet the existing shortage. This occurs because the local government has not yet provided maximum post-harvest institutional security.

Table 5. The Price of Unhulled Rice in Siak Regency, 2018

\begin{tabular}{|l|c|c|c|c|c|}
\hline \multirow{2}{*}{ Sub-District } & \multicolumn{2}{|c|}{ The Price of Unhulled Rice } & \multicolumn{2}{|c|}{ Factors affecting the price of Unhulled Rice } \\
\cline { 2 - 6 } & $\begin{array}{c}\text { Government } \\
\text { Purchase Price } \\
\text { (IDR) }\end{array}$ & $\begin{array}{c}\text { Farmer } \\
\text { Purchase Price } \\
\text { (IDR) }\end{array}$ & $\begin{array}{c}\text { Distance from the } \\
\text { district capital } \\
(\mathrm{km})\end{array}$ & $\begin{array}{c}\text { Land area } \\
\text { (ha) }\end{array}$ & Road Condition \\
\hline Bunga Raya & 3,700 & 4,700 & 25 & 2,252 & Good \\
\hline Sabak Auh & 3,700 & 4,600 & 65 & 1,380 & Good \\
\hline Sungai Apit & 3,700 & 4,500 & 60 & 823 & Not Good \\
\hline Sungai Mandau & 3,700 & 4,600 & 90 & 906 & Good \\
\hline
\end{tabular}

\subsection{The Agrotourism potential}

The rice fields in Siak Regency, especially Bunga Raya District, are currently used for rice cultivation as well as for tourism objects or better known as agro-tourism. From the results of this agro-tourism research, it turns out that it provides opportunities for farmers and local communities to improve the quality of life by utilizing their agricultural resources.

[22] states that tourism development can be an opportunity for local farmers to increase their income and quality of life for their families. The results of a study by [23] in Nigeria show that the abundant agricultural resources have the potential to be developed as agrotourism, which is why the local government is working with the private sector and the local community to try to advance agro-tourism in Siak Regency, especially Bunga Raya District because it is felt there is a contribution to the economy of the local community.

There are quite a lot of tourist objects offered today, however what is becoming a trend and in interest are the objects of activities in rice cultivation, such as a tractor plowing competition, a competition to catch rats in the rice fields before planting the fields. Football matches in the mud fields after the rice fields are plowed, prayers and meals together at the rice fields before they go down to the rice fields, which are followed by the entire surrounding community as well as rice planting and harvesting competitions, both manually and using machines. Manuals are usually followed by women and using machines followed by men.

The processing and harvesting of lowland rice farming manually as well as mechanization has become a popular tourism commodity. The attraction of traditional rice cultivation and harvesting is one way of introducing students as the younger generation, especially to the younger generation who live in urban areas, about the origin of food and how to get it. This is because many of them do not know rice fields, which results in a lack of appreciation for the food that is consumed every day and the farmers who produce it and as an effort to preserve local wisdom in the process of rice cultivation.

The attraction of mechanized rice cultivation and harvesting is aimed at attracting the interest and enthusiasm of the younger generation to love and enjoy farming again. Give an example that farm work is not always outdated and outdated. The existence of agricultural tools and machinery is expected to be able to attract young workers in rural areas not to move to cities, because the younger generation prefers to work in industrial sectors that are considered clean and more modern, compared to working in the agricultural sector which is still considered a field of work dirty and not promising.

The packaging of attractive attractions from year to year causes the number of tourists visiting the research 
sites to increase. The increase in the number of visitors, especially student and student visitors who want to stay in the village and learn rice farming, gives hope that agriculture through tourism will have a positive impact on growing the interest of the younger generation in farming. The increase in the number of visitors also has a positive impact on the local community, especially in the economic sector, both people who are involved directly or indirectly. People who are directly involved in agro-tourism based on lowland rice farming are farmers and agricultural attraction instructors, while those who are indirectly involved are inn owners, restaurants, art groups, traders, groups of souvenirs and souvenir makers as well as security officers/parking attendants. Over time, it has begun to be realized that agriculture does not only function as a food producer but has many roles or is multifunctional.

Agro-tourism as one of the multi-functions of agriculture is growing rapidly not only in Siak Regency but in all parts of the world because it has proven to have a positive impact on society, therefore the infrastructure to develop lowland rice agro-tourism as an alternative economic source needs to be prepared, such as adequate roads, irrigation facilities/irrigation, telecommunications networks, banking facilities, production facilities for processing agricultural products and public facilities, and other social facilities.

[24] State that agro-tourism is an option in agricultural diversification in Kansas because of its potential to increase people's income. A study conducted by [25], in Peninsular Malaysia, shows that agro-tourism is useful in promoting sustainable rural development. Agro-tourism increases community social empowerment, strengthens social ties between communities, increases income, is diversification of economic activities, provides employment and alleviates poverty, and prevents urbanization.

Government support in developing agro-tourism in Siak Regency, especially in Bunga Raya District, one of which is by carrying out cycling activities around the rice fields to see views of green and yellow rice, while enjoying snacks sold by the surrounding community. This activity is held regularly at least every Thursday, replacing morning exercise, employees, and the community start and finish at the sub-district office on the Siak-Pakning crossing.

The agro-tourism program in Sabak Auh and Sungai Mandau Subdistricts has also begun, in the Sungai Mandau, some activities support the development of local agro-tourism with the establishment of the Agricultural Technology Park. The purpose of agricultural technology park is to turn Sungai Mandau District into a center for agricultural technology development in Siak Regency, previously this rice field was an ordinary rice field. Currently, agricultural technology park has become an apprenticeship location for students and students as well as a training venue for rice cultivation, mina rice, shallots, papaya, and duck livestock.

Besides functioning as a training ground, agricultural technology park also functions as an agricultural tourism object (agro-tourism) with the availability of monitoring towers, farmer stalls, and fruit gardens. Since the introduction of the agricultural technology park location on August 28, 2017, until it was inaugurated on August 3, 2018, by the Regent of Siak, many visits have come from various groups, such as students, students, farmers groups and other agricultural observers. Visits to the Sungai Mandau agricultural technology park until August 2018, recorded 200 students from agricultural schools and kindergartens in Sungai Mandau District. The 150 students consist of students from Riau University, Riau Islamic University, Sultan Syarif Kasim State Islamic University, and Andalas University. The 250 farmers come from farmers in Siak, Kampar, and Meranti Districts. Other visitors were 75 people, consisting of extension agents, NGOs, KTNA Head of Central Java Agricultural Technology Research Center and Head of Research Service Collaboration and Head of Solok Tropical Fruit Research Institute with papaya researchers, researchers from the Center for Rice Plants, researchers from the Center for Land Resources Agriculture and so on.

\subsection{Farmers Income Level andFeasibility of Lowland Rice Farming}

Income is the amount received by residents for work performed during a certain period, whether daily, weekly, monthly, or annually. In the end, business activities will receive income in the form of monetary value received from product sales fewer costs incurred. Income is the difference between revenue and total costs incurred during one growing season [26].

Income for respondent farmers to meet their family needs. The amount of income obtained from farmers. Therefore, a large amount of production was produced and the selling price was acceptable at that time. The greater the production produced and the higher the selling price, the higher the income the farmers will get. Income is an indicator to measure the welfare of a person or society. According to [27], an increase in production can be an indicator that we believe is a measure of one's welfare, but the high production in a farm does not guarantee that income is earned, received and input costs received and input costs received. Community income is a reflection of the economic progress of a region, for more details about the costs and income of farmers/ha/growing season in each district can be seen in Table 6 . 
Tabel 6. Analysis Of Costs, Revenues And Income Of Lowland Rice Farming /Hectare/Growing Season

\begin{tabular}{|c|c|c|c|c|}
\hline \multirow{2}{*}{ Description } & \multicolumn{4}{|c|}{ Sub-district } \\
\hline & Bunga Raya & Sabak Auh & Sungai Apit & Sungai Mandau \\
\hline \multicolumn{5}{|l|}{ Cost of production facilities (IDR) } \\
\hline - Seed (IDR) & 225,000 & 225,000 & 225,000 & 225,000 \\
\hline - Urea & 300,000 & 250,000 & 250,000 & 250,000 \\
\hline - TSP & 350,000 & 200,000 & 200,000 & 200,000 \\
\hline$-\mathrm{KCl}$ & 500,000 & 400,000 & 400,000 & 400,000 \\
\hline - Organic Fertilizer & $1,200,000$ & 600,000 & 300,000 & 300,000 \\
\hline - Biological Agents & 500,000 & 300,000 & - & - \\
\hline - Oil for the water pump & 500,000 & 500,000 & - & 500,000 \\
\hline - Liquid organic Fertilizer & 500,000 & - & - & - \\
\hline - Chemical pesticides & 800,000 & 400,000 & 400,000 & 400,000 \\
\hline Total production facilities & $4,875,000$ & $2,875,000$ & $1,775,000$ & $2,275,000$ \\
\hline \multicolumn{5}{|l|}{ Labor costs (IDR) } \\
\hline - Tillage & 700,000 & 700,000 & $1,000,000$ & $1,000,000$ \\
\hline - Nursery & 300,000 & 300,000 & 300,000 & 300,000 \\
\hline - Bund Service & 300,000 & 300,000 & 300,000 & 300,000 \\
\hline - Planting & 600,000 & 600,000 & 900,000 & 900,000 \\
\hline - Replant & 150,000 & 150,000 & 150,000 & 150,000 \\
\hline - Weeding & 600,000 & 400,000 & 400,000 & 400,000 \\
\hline - Fertilization & 400,000 & 200,000 & 200,000 & 200,000 \\
\hline - Spraying plant pests & 500,000 & 200,000 & 200,000 & 200,000 \\
\hline - Irrigation costs & 300,000 & 300,000 & - & 300,000 \\
\hline - Harvest costs & $3,722,400$ & $2,760,000$ & $2,538,000$ & $2,704,800$ \\
\hline Total labor costs & $7,572,400$ & $5,910,000$ & $5,988,000$ & $6,454,800$ \\
\hline Total costs $1+2$ & $12,447,400$ & $8,785,000$ & $7,763,000$ & $8,729,800$ \\
\hline \multicolumn{5}{|l|}{ Input } \\
\hline - Production (ton/ha) & 6,6 & 5,0 & 4,7 & 4,9 \\
\hline - Price of unhulled rice (IDR/kgs) & 4,700 & 4,600 & 4,500 & 4,600 \\
\hline - Value (IDR) & $31,020,000$ & $23,000,000$ & $21,150,000$ & $22,540,000$ \\
\hline Income (IDR) & $18,572,600$ & $14,215,000$ & $13,387,000$ & $13,810,200$ \\
\hline BCR & 1.49 & 1.62 & 1.72 & 1.58 \\
\hline RCR & 2.49 & 2.62 & 2.72 & 2.58 \\
\hline
\end{tabular}

Table 6 describes the average production by respondent farmers in Siak Regency during one planting season of 4,700-6,600 kg unhulled rice/ha/planting season with an average price of IDR 4,500-4,700, so the total yield obtained by farmers is IDR 21,150,000$31,020,000 /$ ha/planting season.

The total costs incurred by the respondent farmers were IDR 7,763,000-12,447,400/ha/planting season on average. Referring to total results obtained and the total costs incurred, the amount of income earned by farmers in Siak Regency is IDR 13,387,000-18,572,600/ha/planting season with an RCR value of 2.49-2.72. The BCR value of all districts is also the same, which is more than 1 . This means that rice farming activities in Siak Regency are economically feasible and profitable.

\section{CONCLUSION}

Based on the identification of several economic factors that are thought to affect the sustainability of rice farming, it is known that:

1. The availability of farmer's capital is the main factor that causes rice farming to not sustainable, with the proportion of farmers who lack capital of $59.11 \%$.

2. The availability of production facilities, price of unhulled rice, the potential for agro-tourism, economic efficiency and farmer income have played a positive role in the sustainability of rice farming.

3. Rice farming in Siak Regency is economically profitable and feasible to continue with RCR and BCR values of more than 1 . 


\section{REFFERENCES}

[1] Serageldin I. and Steer A., "Making development sustainable : from consept to action enviromentally sustainable development occasional paper series No. 2.", The Word Bank, Washinton D.C. 1994.

[2] Liu F. and Zhang H., "Novel Methods to Assess environmental, economic, and social sustainability of main agricultural regions in China", Agronomy for Sustainable Development, vol. 16, no. 3, pp. 621-633, 2013.

[3] Thanha N. V. and Yapwattanaphun C., "Banana farmers adoption of sustainable agriculture practices in the Vietnam uplands: the case of Quang Tri Province", Agriculture and Agricultural Science Procedia, vol. 5, pp. 67-74, 2015.

[4] Badan Pusat Statistik "Siak dalam Angka Tahun 2009”, Badan Pusat Statistik Kabupaten Siak, Siak Sri Indrapura. pp. 180, 2010.

[5] Badan Pusat Statistik "Siak dalam Angka Tahun 2014”, Badan Pusat Statistik Kabupaten Siak, Siak Sri Indrapura, pp. 193, 2015.

[6] Peraturan Daerah Nomor 02 Tahun 2014 Tentang Perlindungan Lahan Pertanian Pangan Berkelanjutan. 2014.

[7] Ryan, Thomas P., "Sample Size Determination and Power", John Wiley \& Sons. Hoboken, New Jersey, 2013.

[8] Riduwan dan Sunarto, "Pengantar statistika untuk pendidikan, sosial, ekonomi, komunikasi dan bisnis (lengkap dengan aplikasi SPSS 14)", Alfabeta, Bandung, 2009.

[9] Marimin, "Teknik dan Aplikasi Pengambilan Keputusan Kriteria Majemuk", Jakarta, Grasindo, 2004.

[10] Darus, Saipul B, Ujang P., "Analisis ekonomi padi sawah di Kecamatan Rambah Samo Kabupaten Rokan Hulu. Jurnal Dinamika Pertanian, vol. 30, no. 2, pp. 171-176, 2015.

[11] Bank Indonesia, "Laporan Perekonomian Indonesia 2016", Bank Indonesia, Jakarta, 2016.

[12] Omobolanle LO and Ewuola S OLU., "Adoption bahavior of farmer in southwest, Nigeria. The case of soybean farmers", Journal Central European of Agriculture, vol. 6 no. 4, pp. 415-426, 2006.

[13] Bagheri A., Shabanali F.H., Rezvanfar A., Asadi A. and Yazdani S., "Perceptions of paddy farmer towards sustainable agricultural Technologies: case of haraz catchments area in Mazandaran Province of Iran", American Journal of Applied Sciences, vol. 5, no. 10, pp. 1384-1391, 2008.

[14] Hermawan H. dan Andrianyta H., "Peran tambahan modal terhadap pendapatan usahatani padi di Kabupaten Blitar dan Ngawi, Jawa Timur", Jurnal Pengkajian dan Pengembangan Teknologi Pertanian. Balai Besar Pengkajian dan Pengembangan Teknologi Pertanian. Badan Penelitian dan Pengembangan Pertanian. Kementerian Pertanian. Bogor, vol. 16, no. 2, pp. 143-158, 2013.
[15] Jayne T. S, Sieglinda S., Frank P. and Nicholas S., "Sustainable agricultural intensification in an era of rural transformation in Africa", Journal Global Food Security, vol. 20, pp. 105-11, 2019 DOI: https://doi.org/10.1016/j.gfs. 2019.01.008.

[16] Villanoa R., Bright O.A. and Boris B.U., "Farming systems and productivity gaps: opportunities for improving small holder performance in the forestsavannah transition zone of Ghana", Journal Land Use Policy, vol. 82, no. 1, pp. 220-227, 2018. DOI: https://doi.org/10.1016/ j.landusepol.2018.12.010.

[17] Mantiri Rika, Debby C. R. dan Sri M., "Analisis faktor-faktor yang mempengaruhi produksi padi sawah di Kecamatan Dumoga”, Jurnal Pembangunan Ekonomi dan Keuangan Daerah, vol. 18, no. 1, pp. 5-15. 2016.

[18] Komatsuzaki, M., "Agro-ecological approach for developing a sustainable farming and food system", Journal of Developments in Sustainable Agriculture, vol. 6, no. 1, pp. 54-63, 2011. DOI: https://doi.org/10.11178/jdsa.6.54

[19] Lutz J., Barbara S. and Nelson G., "Farmer cooperation as a means for creating local food systems-potentials and challenges" Sustainability, vol. 9, no. 6, pp. 925 https://doi.org/10.3390/su9060925.

[20] Sutoro, Tintin S., Mamik S. dan Kurniawan R.T., "Keragaman malai anakan dan hubungannya dengan hasil padi sawah (Oryza sativa)", Buletin Plasma Nutfah, vol. 21, no. 1, pp. 9-16, 2015.

[21] Sawit M.H., "Reformasi kebijakan harga produsen dan dampaknya terhadap daya saing beras. Orasi pengukuhan profesor riset bidang ekonomi pertanian", Badan Penelitian dan Pengembangan Pertanian. Kementerian Pertanian, 2010.

[22] Handayani S. M, "Agrowisata berbasis usaha tani padi sawah tradisional sebagai edukasi pertanian (Studi kasus Desa Wisata Pentingsari)", Jurnal Habitat, vol. 27, no. 3, pp. 133-138, 2016.

[23] Nnadi and Akwiru, "otentials ofagro-tourism for rural development In Nigeria", Journal of Agriculture And Social Research (Jasr), vol. 5, no. 1, pp. 96-102, 2005.

[24] Amanor-Boadu, Vincent. "Diversification decisions in agriculture: the case of agritourism in Kansas." International Food and Agribusiness Management Review, vol. 16, no. 2, pp. 57-74, 2013.

[25] Hamzah A., "Socio-economic impact potential of agrotourism activities on Desa Wawasan Nelayan community living in Peninsular Malaysia. African" Journal of Agricultural Research, vol. 7, no. 32, pp. 4581-4588, 2012.

[26] Sukirno, "Ekonomi Pembangunan. Proses, Masalah dan kebijakan" Kencana Prenada Media Group, 2006.

[27] Rustam W., "Analisis Pendapatan Dan Kelayakan Usahatani Padi Sawah Di Desa Randomayang Kecamatan Bambalamotu Kabupaten Mamuju Utara", Jurusan Agribisnis Fakultas Pertanian Universitas Tadulako Palu, e-J Agrotekbis, vol. 2 no. 6, pp. 634- 638, 2014 